\title{
The Importance of Partnerships: The Relationship between Small Businesses, ICT and Local Communities
}

\author{
Darlington Onojaefe \\ Cape Peninsula University of \\ Technology, Cape Town, \\ South Africa
}

onojaefed@cput.ac.za

\author{
Marcus Leaning \\ Trinity College, \\ University of Wales, \\ Carmarthen, UK
}

m.leaning@trinity-cm.ac.uk

\begin{abstract}
The deployment of new technologies such as the Internet is often understood to positively change the way that business works. However it is important to realise that success is not automatic and a number of other factors must also be considered. In this paper it is argued that a wider range of skills is needed than just technical skills, and a wider vision is needed than just the vision of one business. Small businesses, widely considered a suitable vehicle for sustainable development, must be seen in the context of their communities, for their relationship with public sector agencies and other supporting and regulatory bodies, and as partners to much larger businesses. This paper is based on small-scale qualitative fieldwork conducted with small businesses that make extensive use of ICT located in Cape Town, South Africa and Swansea in South Wales, a deprived region of the UK. It was found that for businesses to succeed a range of competencies are by business managers needed that facilitate relationships and partnerships, these are in addition to the skills needed for simple internal operational issues. Moreover as the nature of partnerships change the mix of required competencies vary from one circumstance to another. A model is presented that shows some of the critical relationships between the Internet (on the one hand) and the stakeholders of a business and the relationships with them (on the other).
\end{abstract}

Keywords: Partnership management, small business, ICT, social impact, community informatics, business development

\section{Introduction}

The use of information and communication technologies - especially the Internet - is often understood to be changing the way that businesses, governments and elements of civil society work. It is a dominant belief that the widespread deployment of ICT will lead to benefits for all. Indeed

Material published as part of this publication, either on-line or in print, is copyrighted by the Informing Science Institute. Permission to make digital or paper copy of part or all of these works for personal or classroom use is granted without fee provided that the copies are not made or distributed for profit or commercial advantage AND that copies 1) bear this notice in full and 2) give the full citation on the first page. It is permissible to abstract these works so long as credit is given. To copy in all other cases or to republish or to post on a server or to redistribute to lists requires specific permission and payment of a fee. Contact Publisher@InformingScience.org to request redistribution permission.
ICTs have been understood as being able to: energise business systems (Gates, 2000), empower citizens (Gore, 1994) and even contribute to social and psychological well-being (Cole, et al., 2001). It should be noted however that although technology has been used to improve the quality and speed of human communication, it has not been universally effective in ensuring human and 
societal development. New research is needed to address this problem.

Gurstein (1999) refers to this new field of research as community informatics - "the social appropriation of information technology for local benefits". He advocates association of community development initiatives with the opportunities offered to business presented by information and communication technologies. Much research in the field of Community Informatics argues for such close linkages between community goals and the use of ICT. Through the use of ICT community initiatives may seek to locally resolve issues, such 'empowerment' is widely regarded as a more sustainable pathway to development than top-down, universal technological 'fixes' - a route widely advocated by academics in the field (see Selwyn \& Gorrard, 2002 for example). Indeed Community Informatics advocates a direct, practice-orientated approach to the use of ICT in communities.

Moreover, it is important to involve 'local' organisations in the deployment of ICT as the effects of ICT upon communities will not be universal, as several authors note ICT should be regarded as heterogeneous in their effects, the may cause different effects in different situations (Selwyn \& Gorrad, 2002, Leaning 2005). Without community involvement, the deployment of ICT for business purposes and small businesses themselves may founder.

\section{Purpose of this Paper}

In this paper, based on fieldwork conducted with the small businesses that make extensive use of ICT in Swansea, South Wales, a deprived region of the UK and Cape Town in South Africa, we advocate partnership between all actors involved in the deployment of ICT and especially those involved with the business community. While this would seem an obvious endeavour there are cases in which stakeholders within communities have not been involved; for example, it is reported that the Caribbean states are building a digital inclusion programme for schools without any emphasis on effective use (Menou, Poepsel \& Stoll, 2004 p. 46). The use of ICT by businesses is now a widely accepted phenomenon and much research exists on this issue (see for example Ng, Pan \& Wilson, 1998). We concur with this research but argue that in addition to the technical requirements other competencies are need for business success. We contend that a holistic view of management and partnership is vital to the success of small businesses and that the competencies required in establishing and maintaining such partnerships are of key import. We offer a model for the effective management of relationships by small businesses based on an examination of stakeholders' interests.

\section{Research Method}

The research for this paper was carried out by the authors in their respective countries. It involved a number of interviews with owners/ managers of small business that made extensive use of ICT. The initial interviews were exploratory in nature and sought to identify problems with the use of ICT for business purposes. Following initial analysis a number of respondents were reinterviewed and specific issues were raised and clarified. The initial interviewees were identified through personal contacts of the authors; later interviewees were then reached through 'snowballing' (Heckathorn, 1997; Salganik \& Heckathorn, 2004) from the first contacts. In total 17 ownermanagers of micro and small businesses were consulted, ( 9 in South Wales, 8 in Cape Town). These businesses were either in retail or in business-to-business service and goods provision sectors. A number of points need to be made in relation to the research methods used.

First, this research was not intended to be comprehensive - small numbers of businesses were interviewed to identify how they use ICT in two disparate locations. The extent of ICT usage may not be typical of businesses and varying degrees of usage was identified in the sites studied. 
Second, the formal reliability of the research finding cannot be established - the information uncovered may not be reproduced if similar interviews were carried out again. Instead, as with much qualitative research, this research offers no short answers and may raise more questions than it answers. Indeed this form of exploratory research in not concerned with discerning definite "facts" about the social world or about business practices, rather it is useful in "relation to the development of theory" (Hammersley \& Atkinson, 1992, p.23). The research is intended to draw out new areas of study and new issues to investigate (Creswell, 1994) these new areas are addressed below.

Third, the selection of sites, being very different, posed a number of distinct research problems in their own right. It is acknowledge that selection of sites was based on convenience rather than research design but we do not believe that this invalidates the research. Swansea and Cape Town are vastly different research locations and societies. The differences in personal wealth and general quality of life are significant and considerable. The Economist quality of life Index for 2005 places the UK 29 (towards the lower end of the spectrum of industrialised countries) and South Africa 92 (Economist, 2005 p.4). More over the differences between the two societies in terms of infrastructure development are of course huge. Despite this there were a number of similarities in terms of the difficulties faced by small businesses in these locations. There is rarely enough time or money for small businesses to do all the things they wish to do, regardless of the country in which they operate. We contend that these similarities, and the solutions developed to deal with them outweighed the differences. Therefore, while caution should be expressed in comparing the societies the nature of research conducted does not mean that using such disparate locations invalidate the findings.

The use of ICT was found to be mixed: in some instances this use was quite extensive, with one business trading primarily online. In other instances (the majority for that matter), and of particular interest to the subject of this paper, ICT usage was quite small but still key to business success. These businesses are the primary focus of this paper. Those businesses that made partial use of ICT for a particular business task, such as sourcing cheap materials, the most economical means of accessing the technology was through public and private access points.

\section{Community and Small Businesses Development as a Partnership Phenomenon}

A holistic approach to economic development of communities is important, as it combines the many factors affecting social, economic and political relations in human interaction and partnership (Keeble \& Loader, 2001 p.3). Partnership is especially important because we must be concerned with the development, deployment and management of community information systems that are formulated with, and by, communities - to solve their social, economic and political problems (Clement et al, 2004, p.13). This is only possible through a partnership with those agencies that are critical to solving those problems, such as public service departments and banks.

In developing and implementing development policies, many national governments and transnational agencies have identified small businesses as an engine of sustainable economic development. For example Dervis of the United Nations Development Programme advocates the use of small business as a key means of poverty alleviation (Dervis, 2005). In Wales, the Welsh Assembly Government [WAG], (2002) places considerable emphasis on small businesses as a means of economic growth. Similarly, the South African government identifies small business development as the bedrock of economic growth, although the overly optimistic aspirations of policy-makers could undermine the viability of inclusive long-term partnerships (Davies \& Smith, 2004 p.65). Small businesses are seen as offering a new way forward for development both in underdeveloped countries and in the developed world. Such an approach represents a paradigm shift from the former macro-level initiatives to alleviate poverty through state-level activities. The UN Sec- 
retary General Kofi Anan illustrated this when he said: "It is the absence of broad-based business activity, not its presence that condemns much of humanity to suffering. What is Utopian is the notion that poverty can be overcome without the active engagement of business" (Dervis, 2005).

Economic activities should be encouraged through the establishment of new, small businesses that take advantage of the available information and communication technologies, then partnership becomes even more important, because e-commerce (as it is generally known) concerns the sharing of information with business partners in mutually beneficial ways (Hagen, 2002). It is not sufficient just to run a business, it is also necessary to manage partnerships in new ways, often based on new technology-related opportunities.

Small businesses are believed to be important economic development, access to digital technologies and the capability to achieve effective use are particularly important - policies alone are not enough. In growing and strengthening the entrepreneurial capability of small businesses, a wider range of skills and competencies is required than has previously been the case.

Small businesses cannot do it alone - they are inevitably part of a wider network of larger businesses (that partner with them), public administrations (that support and regulate them), and a civil society (that provides them with both human resource and markets for goods and services). Hence, the relationship between the economic appropriation of technology, local communities and small businesses requires some kind of engagement with role players, to overcome any impediments in achieving partnership, especially with technology. This argument can be extended, so that community engagement becomes the very pillar of the information society that accommodates small businesses and all that goes with them, including information and communications technologies and partners of different kinds (Erwin \& Taylor, 2004 p.23).

\section{The Role of ICTs in Small Business Development}

The growing number of small businesses with access to computers and the Internet emphasises the need to make effective use of information and communications technologies. Though investment in these technologies is increasing, the benefits for users have remained limited and research has attempted to address these limitations.

Various experts have identified barriers to effective Internet technology use, such as: limited access to facilities, outdated hardware and software, inadequate skills, minimal support, time constraints and even a simple lack of interest in, or knowledge of, the necessary technical aspects (Berg, Benz, Lasley \& Raisch, 1998; Clark, 2000). However, some small businesses that have managed to integrate technology into their operational and management processes have been studied, and have been recognised as most suitable partners for other businesses in a societal and political context (O’Bannon \& Judge, 2004 p.197).

There is an emerging concept of technology-enhanced partnership management; those businesses that are not prepared to face the changes and challenges of technology-enhanced partnership management risk disadvantaged. O'Bannon \& Judge, (2004, p.198) explain that a readiness to adopt technology enhances the prospects for successful partnership, and for successful partnership management. The desire to create conducive environment for small businesses to enter into partnerships with civil society provides basis for the deployment of technology in support partnership management (Pan et al, 2006). It is assumed that partnerships between business, government and civil society already exists but, the development and deployment of ICT in support of this effort is important to its success. Therefore, all partners in partnerships should enjoy easy access to and make effective use of ICT in the management of partners' information. ICT should be deployed in a manner that is understood by partners to provide them the necessary support (Palm \& Hansson, 2005). 


\section{Small Business Competencies for E-Commerce}

Small businesses must use a combination of technical and managerial skills to develop and deploy technology effectively, and to enhance partnerships. Investment in information and communications technologies is seen as a key issue, not only for efficiency reasons but for strategic reasons as well. Small businesses can use technology to leverage relationships with their partners, thereby extending their influence over partner strategies and offering the most efficient and effective modes of working. Information relating to partnership activities, from simple transactional information through to information about strategic intentions, can now be shared easily, and is seen by some as an essential factor in process management, representing the beginning of human thought and determined management actions. Macgregor (2005 p.2) defines information as the input to, and output from, the mind, that determines individual actions; when these actions are related to management decisions, the performance of a business and its partners may be affected. Partners lacking either technical or managerial skills will likely take actions that are detrimental to other partners.

\section{Figure 1: Competencies in business}

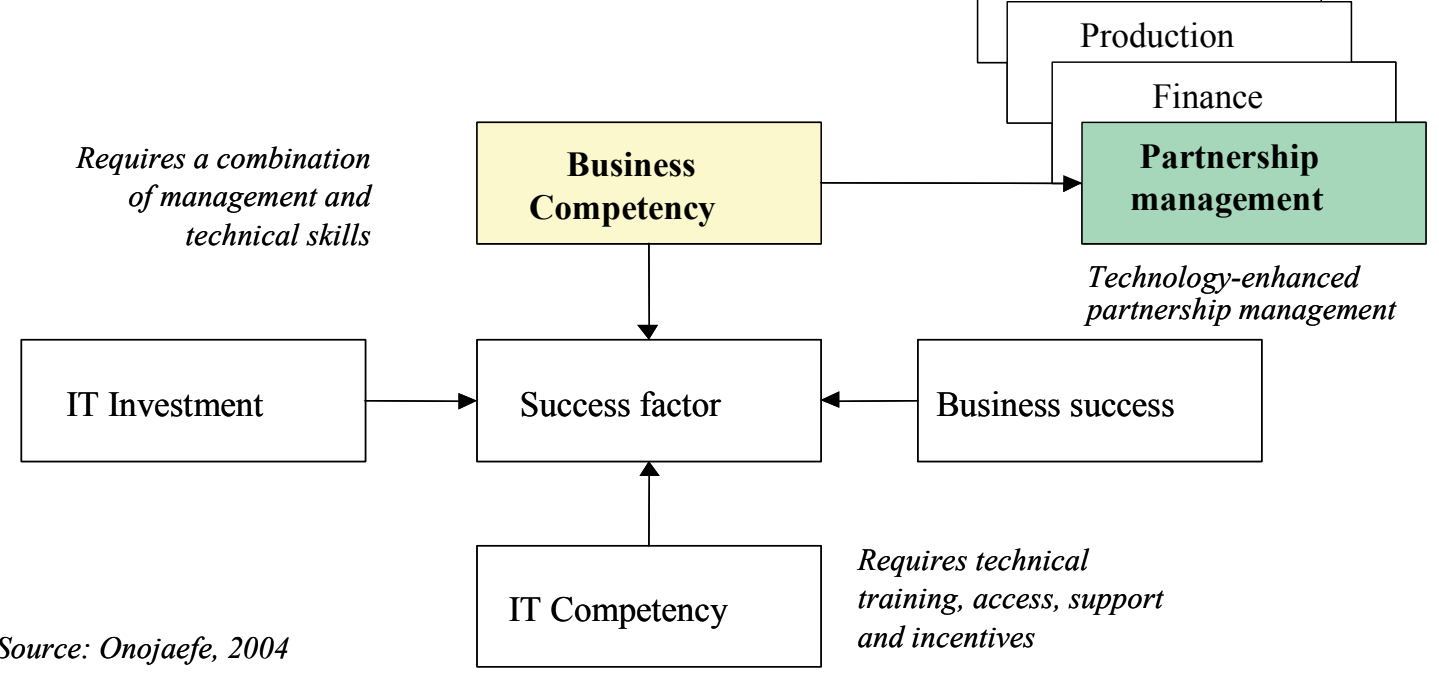

Figure 1 shows how business competencies can be seen as central to successful information technology investments.

- Business competencies come in different kinds: financial affairs must be well managed, production must be controlled, and procurement that is not well executed can lead to serious problems. Partnership management is seen as a new competency that is important to any business that is striving to develop new kinds of partnership, essentially driven by new technological opportunities such as e-commerce (upper right portion of the figure).

- Business success is seen as dependent on a number of different success factors - possibly not all of which are currently understood in the new field of e-commerce. These individual success factors relate directly to business as well as technology competencies, and to the quality of the technology investment (central and lower left portion of the figure).

In summary, where a partnership is based in any way on technology, success requires a combination of management and technical skills, and the technical skills require appropriate training and support. 


\section{The need for harmonisation}

Romm \& Taylor (2000); O'Neil (2001) emphasise that the prospect of community informatics projects is directly linked to harmonisation of interests; they argue that a lack of social harmony is often associated with less successful outcomes in CI projects. Harmonisation of interests is assisted by a full and proper understanding of the technology-related benefits offered to those who are concerned, typically (in our area of interest) the community and the small businesses that wish to serve it, or larger businesses that might choose smaller businesses to provide selected goods and services. A fulsome view of the harmonisation of community, business and the technology interests, all in support of the relationship between them, will help to meet the objectives of information and partnership management. The changing and challenging attributes of information and communications technologies determine that achieving this is simultaneously difficult in theory and cumbersome in practice.

One of the problems is the limitless plethora of information. As people live and work in an era of information saturation that is creating difficulties for small businesses trying to deal with the information aspects of partnership management (Macgregor, 2005). In some instances, useful information has been ignored or discarded because of a lack of an effective information management regime. So, at the same time that some argue that the Internet provides information and facilitates effective management, and that the Internet can be used to improve the quality of partnership among and within partners (Mason \& Gurnstein, 2001) it seems to present quite specific problems that detract from these advantages.

Understanding the business environment is important to the successful involvement of small businesses in e-commerce activities. According to Bytheway \& Dhillon (1996), environmental analysis "of technology trends, competition, economic factors and socio-political aspects" is required, and they also highlight the different kinds of partnership that might prevail: adversarial partnerships have been common in conventional business, but co-operative partnerships are more fashionable (and possibly necessary) in e-commerce. The business culture that exists on either side of a partnership may reinforce or mitigate against successful partnership; the process of harmonising business cultures will have a direct effect on the development and management of appropriate technology-related partnerships.

\section{Factors for success and failure}

In the South Wales region a number of researchers have identified various barriers to increased ecommerce activity. Both Quayle (2001) and Brooksbank, Thomas, Packham \& Morse (2003) identify developing infrastructure and provision of training as a key means of assisting business. Wales has made considerable efforts in addressing the disparity in educational and training attainment between regions of South Wales and the rest of the UK (Brooksbank, Morse \& Thomas, 2000; Thomas, Packham, \& Miller, 2002).

In South Africa, there has been commitment by government to increase citizen access to various services. However, growing disaffection with poor government services and lack awareness of various public-access-point shows that success is far from been achieved. Partnership between government and civil society that is so important in achieving ICT success no longer enjoys the trust and loyalty of civil society because of poverty. In an effort to provide access to government services, the provincial government of Western Cape introduced a project called the Cape Gateway (DeTolly, 2006). The success of this project is seen through the growing socio-economic activities of local communities. Despite its initial success, the relationships between various stakeholders are now being affected with growing resentment about distance-to-access point and opening hours among poor local communities (Alexander, et. al., 2006). 
The Provincial Government of the Western Cape provides access points in the rural areas through the Cape Gateway Access and this project makes up 5\%of all regional access initiatives. Through this project, communities are provided with access to computers and the Internet, and training on how to use these facilities. The aim of this project is to help small businesses in these rural communities have access to valuable market information. Most of those interviewed acknowledged that there are benefits of information access and the challenges of real market access. While small businesses are empowered through access point, fragile partnerships with stakeholders obliterate the benefit to real business development.

Scott, Diamond \& Smith (1997) studied success factors and, and looked at the establishment of 450 public Internet access points by the Australian government. They found that these access points were grossly under-utilised because they failed to offer private access. The authors therefore recommended that private access be provided through local Internet service providers (ISPs), supplemented by community out-reach support and training. Elsewhere it has been found that a lack of attention to the elaborate interplay between hardware and software undermines sustainable partnerships, despite awareness campaigns, education and training (Simpson, 2005, p.81).

The sustainability of partnerships is largely dependent on the extent to which partners' interests are understood and the process by which these interests are satisfied. Sustainable partnerships demand a process of ongoing social interactions and projects or programmes that are aimed at developing and implementing change, or influencing the attitudes of partners in appropriate ways (Calabrese, 2006). There is a distinction between the development of partnerships (including capacity building and leadership training), and the evident levels of social, education and business capacity within individual partners. While both are important from a partnership point of view, it is suggested that more emphasis should be given to the development of a partnership that implies a deep sense of the recognition of interdependence of person and the importance of working together to realise the objectives of each person's community needs. The development and management of partnerships should then focus on building the capacity of partners for the purpose of both social and business interaction and collaboration. Partners must work together to find solutions to the problems facing them, so that all effort is directed at overcoming common difficulties and establishing a co-operative regime, as identified by (Bytheway \& Dhillon, 1996; Kittelstrom, 2001; Davis, 2002).

\section{The nature of partnerships}

National, provincial and local government efforts to promote small businesses with developmental assistance in both South Wales and South Africa have to deal with the complex issue of sustainable partnership, economic inequalities and change management arising from social appropriation of ICT in a business context. The traditional "horizontal" approach to problem solving through government incentives is slowly changing to a "vertical" approach, requiring expert opinion to solve business problems (Simpson, 2005, p.84). Effective partnership requires "bottom-up" tools and programmes that provide small businesses with the opportunity to engage one another in solving problems of equity, economic empowerment and networking (Onyx \& Bullen, 1997). Indeed the "bottom-up" approach and local capacity building activities as viewed as a key goal by numerous authors and actors in this field. Guernstein and Jeet Sing (2006) argue that India's Right to Information Act, passed in 2005, will offer new opportunities for citizen empowerment.

Many partnership initiatives have been widely developed and implemented, but fail to address information and communications technology inclusion and effective use. To ensure benefits, and a cohesive business management process, information and communications technology should be properly managed for effective use within a partnership, so as to avoid artificial obstacles to partnership formation (Mannion, 1996 p. 2; Popham, 1996; Schuftan, 1996). 
According to Mellahi and Wood (2004), business and social partnerships are often developed for partners and not by them - clearly this will be the case in an unequal partnership where one - the stronger - insists on a style of partnership that they consider advantageous to themselves. A weaker partner is vulnerable to external factors and may be unable to sustain success by responding to the variable circumstances imposed upon them. If the South African government, for example, wants to develop and implement a strategy based on Internet access for small businesses then they should not just be trained in the effective use of information and communications technologies, they must be trained in negotiation skills and in strategic management. Then, perhaps sustainable partnerships between government, small business and their immediate communities will emerge that will support small businesses. This is contrary to the strategies being adopted in developed European countries and the US, which place emphasis on self-help. For partnership to be successful especially in developing countries, harmonious government, community and business partnership is unavoidably necessary (Dervis, 2006).

Early experience indicated that this can be achieved by understanding the needs of the different stakeholders, and by providing finance, technology, hardware and the technical knowledge to support and maintain it (Mason, Heaton \& Morgan, 2004). In this case the Australian Government funded a regional telecommunications infrastructure project with total spending of $\$ 464$ million, to improve both local and regional communications networks. The primary motive of the project was to ensure that stakeholders took ownership of developing and managing a healthy and sustainable community of small businesses, through partnership. It was expected that government support and funding for initiatives of this nature should sharpen the vision and will of the community to be more responsible, more responsive and more proactive to managing the achieved and perceived technology-related benefits for economic growth. Without a co-operative partnership, government projects are doomed to failure, as was found in this Australian case.

\section{Building business and social partnerships}

Other work reinforces the argument that the achievement of sustainable social stability, economic empowerment and business benefits requires the development and management of sustainable partnerships (Cavaye, 1999; Labonte, 1999). Though partnership building suffers from additional complicating factors such as security, trust and the visible and invisible costs involved, a lack of effort to build partnerships can lead to business failure and unattainable national, provincial and local government objectives (Blackwell \& Colmenar, 1999). Where adversarial business practice might even play on these complicating factors for strategic advantage, a well directed business and social partnership empowers, motivates and commits individuals to maximise their contribution to common objectives, with an open and willing attitude to adopt change (Gannon, 1998). Thus, the building of business and social partnerships requires a two-way system of individual empowerment through information and communications technologies, and the strengthening of the partnership network infrastructure (Milio, 1996).

\section{Model for Partnership Management}

Out of this review of early and recent literature and the fieldwork conducted into small business practice, e-commerce and with partnership management issues come a number of important principles:

- Success will not come from technology alone, but from a wider range of management skills.

- A range of business skills will be necessary, but managing partnerships well will be a critical competency that may not be evident in small businesses that are trying to take advantage of the Internet. 
- Partnerships can be seen at different points in a business - in its relationship with its customers (perhaps that is the most traditional one, usually referred to now as "customer relationship management"), with its business partners (of which there are many different kinds, such as suppliers, banks and service providers) and with its staff, who require the requisite competencies if e-commerce is to succeed.

- The quality of these partnerships will be seen through the benefits that derive from them, as seen in some aggregated way that is agreeable to all stakeholders.

This later observation is important, because it is so often the case that a stakeholder will dogmatically refuse to see any point of view or perspective other than their own. But, there is one important concept in modern business that attempts to aggregate all viewpoints: that is the concept of brand equity. It has become so important that corporations even want to include brand equity in their balance sheets, although how this might be done remains debatable.

Some experts see brand equity as the sum of everything that could conceivably comprise the impression that a business creates - not just with customers but with all those that contribute to such an impression including business partners and staff. As a relatively new area of management research, possibly parallel to the emergence of the Internet and certainly stimulated by it, brand management deserves to be taken seriously as a combination of competencies and capabilities that will assist a business - even a small business - to successfully deploy the Internet in its business activities. Not just in marketing, but in all that it does for internal and external stakeholders.

Figure 2 depicts the concepts that arise from this discussion of issues, as impacted on by the adoption of the Internet partnership.

\section{Figure 2: Conceptual framework}

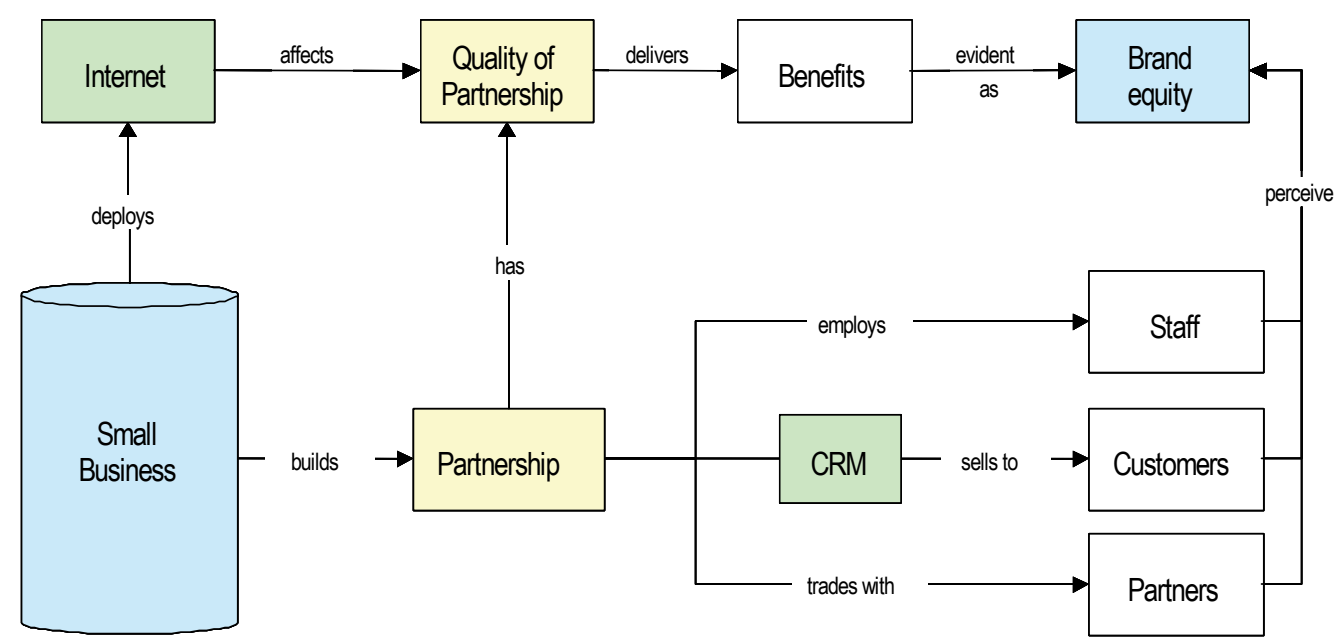

Source: Onojaefe, 2004

The figure can be described as follows:

- Practically, small businesses undertake to build different kinds of relationship with their stakeholders - principally "Customers", "Staff" and business "Partners".

- Two components - "Internet" and "CRM" - represent areas of management action that may or may not enhance the quality of partnerships. 
- Dealing with customers is often referred to as "customer relationship management", or CRM. No doubt the relationship with partners and employees is the subject of similar thinking, and this needs to be investigated.

- "Brand equity" is seen as the sum of all the perceptions of these key stakeholders, based on mutual benefits.

- The lower part of the conceptual framework can be argued to represent "conventional thinking", before the introduction of the Internet.

- The Internet is then shown in the upper left part of the figure and is presumed to impact on the "quality" of a relationship and thereby may or may not have "benefits", and may or may not enhance the quality of partnerships with stakeholders.

- Quality management of partners' relation leads to real benefits, judged not by the quality of the technology implementation, but by the partners themselves.

- The manifestation of these benefits is seen as increased or technologically enhanced quality in relationships with partners, or brand equity, or both.

This conceptual model is being deployed in research that examines the relationships between large financial service companies and their smaller partner businesses, at a time when Internetbased systems are being introduced with the intention of enhancing those relationships. Early experience indicates that success is by no means easy to achieve, and the concepts embraced here are proving helpful in understanding where things can go wrong, by commission or by omission.

\section{Conclusion}

As technology dictates the social and economic development activities of people, the role of information and communications technologies as part of this developmental framework is becoming increasingly important. The success of small businesses relies on partnerships with the small business community generally, the wider business environment, government, civil society and others. The relationship with civil society is particularly interesting as it is, in the end, both the driver of all businesses (through consumer demand) and the source of human resource for all businesses.

Although, the concepts of partnership management exist in traditional management practice, it can be extended to the Internet provided that the components and elements of Internet partnerships are recognised and managed. From an early reading of relevant research, this will require a wider range of management skills than is at present recognised. For it to be successful, there should be an emphasis on (and understanding of) economic, infra-structural, social and human capital (Putnam, 2000). The principles of partnership development and management will not change with changing technology and online partnership management, but the detail will.

This paper has observed that the important business opportunities associated with the Internet can be successfully grasped, but that there are risks that can obliterate the benefits to be gained. An important risk is the mix of management competencies available to a small business, not just to manage the technology but also to manage the complex, soft, issues concerned with relationship management in a changing environment. Adequate technical and managerial skills are needed to ensure mutual benefits from technology investments by partners. Though improved management of partnerships and relationship management could lead to business success, the recognition of brand equity and brand management as an alternative management philosophy to deal with the Internet has been put forward. The framework provided here stands as the foundation for new research that will enhance the prospects for partners, and for good relationship management in all circumstances, especially those related to the introduction of the ICT. 


\section{References}

Alexander, H., Maumbe, B.M. \& Detolly, K. (2006, May). Keeping up with the Joneses: Questioning the pace of e-government in the developing world. Proceedings of the 2006 IST Africa Conference, South Africa, 1-12.

Berg, S., Benz, C.R., Lasley, T.II, \& Raisch, D. (1998). Exemplary technology use in elementary classrooms. Journal of Research on Computing in Education, 31(2), 111-123.

Blackwell, A. \& Colmenar, R. (1999). Transforming policy through local wisdom. Futures, 31(5), 1-2.

Brooksbank, D., Thomas, B. Packham, G. \& Morse, L. (2003). E-Commerce and small and medium-sized enterprises in South East Wales: A clear case for intervention? WEI Working Paper Series Paper 33. Welsh Enterprise Institute, University of Glamorgan Business School. Retrieved September 12, 2004, from http://www.glam.ac.uk/file_download/501

Brooksbank, D., Morse, L. \& Thomas, B. (2000). Learning chamber report: Towards a learning strategy. Cardiff Chamber of Commerce, Cardiff. Retrieved July 12, 2004, from http://www.cardiffchamber.co.uk/

Bytheway, A.J. \& Dhillon, G. (1996). Significance of partnership in the management of inter organisational systems. International Journal of Information Management.

Creswell, J. (1994). Research design: Qualitative and quantitative approaches. London: Sage.

Calabrese, R.L. (2006). Building social partnership through the use of an appreciative inquiry theoretical perspective in a school and university partnership. International Journal of Education Management, 20(3), 173-182.

Cavaye, D.J. (1999). The role of government in community capacity building. Brisbane: Department of Primary Industries.

Clark, K. (2000). Urban middle school teachers' use of instructional technology. Journal of Research on Computing in Education, 33(2), 178-195.

Clement, A. Gurstein, M., Longford, G., Luke, R., Moll, M., Shade, L.R., \& DeChief, D. (2004). The Canadian Research Alliance for Community Innovation and Networking (CRACIN): A research partnership and agenda for community networking in Canada. The Journal of Community Informatics, 1(1), 720.

Cole. J., Suman, M., Schramm, P., Lunn, R., Coget, J. F., Firth, D., et al. (2001). The UCLA Internet report 2001: Surveying the digital future, Year two. Retrieved October 16, 2004, from http://www.digitalcenter.org/pdf/InternetReportYearTwo.pdf

Davies, S. \& Smith, T. (2004). Managing university clinical partnership: Learning from international experience. Higher Education and Management Policy, 16(2), 63-71.

Dervis, K. (2006). Opening Address at the African Plenary on National Strategies for Poverty Reduction and the Implementation of the Millennium Development Goals, 26-28 March 2006, Cairo, Egypt.

Dervis, K. (2005). New models point the way out of poverty. United Nations Development Programme. Retrieved September 2, 2006, from http://content.undp.org/go/newsroom/september-2005/financialtimes-20050913.en?categoryID $=349467 \&$ lang $=$ en

Economist. (2005). Quality of life index, Retrieved February 22, 2007, from www.economist.com/media/pdf/QUALITY_OF_LIFE.pdf

Erwin, G.J. \& Taylor, W.J. (2004). Social appropriation of Internet technology: A South African platform. Journal of Community Informatics, 1(1), 21-29.

Gates, B. (2000). Business at the speed of thought: Using a digital nervous system. London: Penguin.

Gore, A. (1994). The global information infrastructure: Forging a new Athenian age of democracy. Intermedia, 22 (2), 4-7. 
Gustein, M. (1999). Flexible networking, information and communications technology and local economic development. First Monday, 4(2).

Hagen, R. (2002). Globalisation, university transformation, and economic regeneration: A UK case study of public/private sector partnership. International Journal of Public Sector Management, 15(3), 204218.

Heckathorn, D.D. (1997). Respondent-driven sampling: A new approach to the study of hidden populations. Social Problems. 44, 174-199.

Hammersley, M. \& Atkinson, P. (1983). Ethnography: Principals in practice. (reprinted 1992) London: Routledge.

Kittelstrom, A. (2001). The one and the many: WJ and his context. Streams of William James, 3(1), 13-22.

Labonte, R. (1999). Social capital and community development: Practitioner emptor. Australia and New Zealand Journal of Public Health, 23(4), 430-433.

Leaning, M. (2005). The modal nature of ICT: Challenging the historical interpretation of the social understanding and appropriation of ICT. The Journal of Community Informatics. 2(1), 35-42.

Macgregor, G. (2005). The nature of information in the twenty-first century: Conundrums for the informatics community. Library Review, 54(1), 10-23.

Mannion, J. (1996). Partnership, participation and capacity building: rural development based on local bottom-up strategies. Leader Magazine. Retrieved March 29, 2006, from http://www.ruraleurope.aeidl.be/rural-en/biblio/defis/art02html

Mason, B., Heaton, N. \& Morgan, J. (2004). Social partnership strategies in two health services trusts. Personnel Review, 33(6), 648-664.

Mason, D. \& Gurstein, M. (2001). Community informatics: Enabling communities with information and communications technologies. Online Information Review, 25(1), 66-74.

Mellahi, K. \& Wood, G.T. (2004). Variances in social partnership: toward a sustainable model? International Journal of Social Economic, 31(7), 667-783.

Menou, M.J., Peopsel, K.D. \& Stoll, K. (2004). Latin American telecenters: It is a long way to TIC perary. Journal of Community Informatics, 1(1), 39-57.

Milio, N. (1996). Engines of empowerment. Ann Arbor: Health Administration Press.

Ng, Pan, Y.G. \& Wilson, T.D. (1998). Business use of the World Wide Web: A report on further investigations. International Journal of Information Management, 18(5), 291-314.

O’Bannon, B. \& Judge, S. (2004). Implementing partnerships across the curriculum with technology. Journal of Research on Technology in Education, 37(2), 197-213.

Onojaefe, D.P. (2004). Small business use of Internet branding for e-commerce benefits. (Doctoral dissertation forthcoming, Cape Peninsula University of Technology).

Onyx, J., \& Bullen, P. (1997). Measuring social capital in five communities in NSW: a practitioner's guide, working paper 41. Coogee, Australia: Management Alternatives Pty. Ltd.

Palm, E, \& Hansson, S.O. (2006). The case for ethical technology assessment (eTA). Technological Forecasting and Social Change, 73(5), 543-558.

Pan, S., Tan, C., \& Lim, E.T.K. (2006). Customer relationship management (CRM) in e-government: A relational perspective. Decision Support Systems, 42, 237-250.

Popham, J. (1996). Empowerment through community enterprise. Local Government Policy Making. 23(2), 26-30.

Quayle, M. (2001). E-Commerce: The challenge for Welsh small and medium size enterprises. Business Week in Wales Lecture, Cardiff International Arena, Cardiff, 16 May, 14 pages. 
Romm, C. \& Taylor, W. (2000). Explaining community informatics success prospects: the authonomy/harmony model. Proceedings of DIAC 2000 - Shaping the network society: The Future of the Public Sphere in Cyberspace, Computer Professionals for Social Responsibility, Seattle, WA.

Salganik, M.J. \& Heckathorn, D.D. (2004). Sampling and estimation in hidden populations using respondent-driven sampling. Sociological Methodology, 34, 193-239.

Scott, M., Diamond, A., \& Smith, B. (1997). Opportunities for communities: public access to networked IT. Canberra, Department of Social Security.

Schuftan, C. (1996). The community development dilemma: what is really empowering. Community Development Journal, 31(3), 260-264.

Selwyn, N., \& Gorard, S. (2002). The information age: Technology, learning and exclusion in Wales. Cardiff: University of Wales Press.

Simpson, L. (2005). Community informatics and sustainability: why social capital matters. The Journal of Community Informatics, 1(2), 79-96.

Thomas, B., Packham, G. \& Miller, C. (2002). Technology transfer policy in Wales and the implications for the management of technological innovation in Welsh SMEs, International Journal of Applied Management, 3(3), 217-246.

Welsh Assembly Government. (2002). A winning Wales: The national economic development strategy of the Welsh assembly government. Retrieved September 12, 2004, from http://www.elwa.ac.uk/doc bin/SkillsObservatory/awinningwales.pdf\#search=\%22wales $\% 20$ National \%20Economic $\% 20$ development $\% 20$ strategy $\% 22$

\section{Biographies}

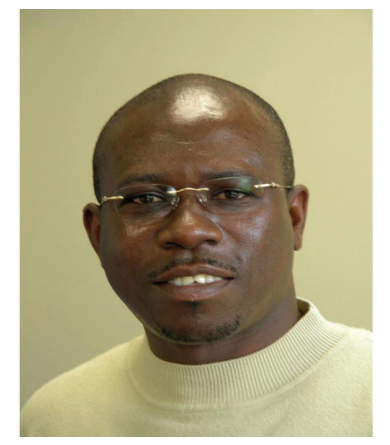

Darlington Onojaefe is an experienced brand/marketing consultant, business analyst, researcher and strategist. His experience has been gained as a consultant in corporations in Nigeria and South Africa. He is currently a doctoral candidate at the Cape Peninsula University of Technology and is managing director of Netega Consulting cc. Darlington was a Visiting Research Fellow at Trinity College, University of Wales in 2006.

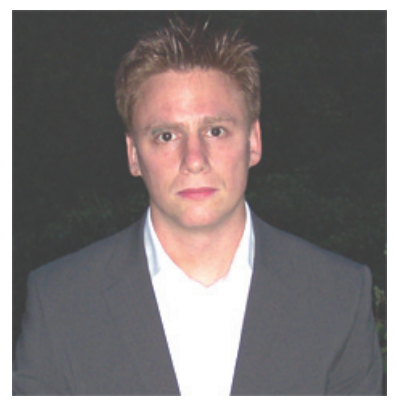

Dr Marcus Leaning is a senior lecturer in media theory and digital media production and is subject leader in Advertising Studies in the School of Creative Arts and Humanities, Trinity College, University of Wales. He teaches and researches media theory and social and political aspects of ICT and has consulted for a number of universities, national and international agencies in these fields. 